\title{
The Effect of Different milk types and its yoghurt by various types of Bacterial Culture on Rats induced to Diabetes.
}

\author{
Usama El-Sayed Mostafa, Yasser Mohamoud Ebrahim, \\ Ereny Wilson nagib, Nada Mohamed Afifi
}

\begin{abstract}
Diabetes is a global health problem in the world. Probiotic therapies are going to be an effective alternative therapeutic strategy in the treatment and management of diabetes. The objective of this study was to evaluate the effect of different milk types, conventional yoghurt and probiotic yoghurt from bifidobacterium on serum blood glucose, lipid profile, liver and liver enzymes for rats induced to diabetes .In this study, two strains of conventional yogurt, Lactobacillus Bulgaricus and streptococcus salivarius and in combination with either probiotics bacteria bifidobacteria infantisandBifidobacteria longum B6 for the production of fermented soymilk and cow milk for feeding 96 male albino rats induced with STZ.Results revealed that fermented soymilk by Bifidobacteria was able to significantly decrease glucose levels, total cholesterol concentrations and triacylglycerols compared to conventional yogurt types and milk types.In conclusion soy-protein consumption reduces serum blood glucose and lipid profile for rats induced to diabetes.
\end{abstract}

Key words: Soymilk, Cow milk, Whey protein,yogurt,serum blood glucose, lipid profile.

\section{Introduction}

Type 2 diabetes mellitus (T2DM) is the main form of diabetes and comprises more than $90 \%$ of people living with diabetes mellitus, worldwide. As the 21 st century, has the 
most diabetogenic environment in human history, it is estimated that the current prevalence of 415 million, will reach 642 million people in 2040 (IDF, 2016). Cardiovascular disease, as one of several chronic disorders, is the major complication of type 2 diabetes mellitus (T2DM). Cardio-vascular disease may result from associated abnormalities of plasma lipid and lipoprotein metabolism (Dunn, 2010). Alteration in plasma lipid and lipoprotein profile has been documented in diabetic patients (Shafrir and Raz, 2003). There are products may directly promote atherosclerosis throughchanges in endothelial, macrophage, and smooth muscle cells functions. Therefore, improving dyslipidemia would be effective to prevent complications of diabetic patients (Rader, 2007).

Plants and animal products are a rich source of various functional foods, which havehealthbenefits. Probiotics are one of the functional foods that link diet and health. Probiotics "For Life" are living, health-promoting microbial food ingredients that have a beneficial effect on humans (Chuayana et al., 2003).

The primary probiotic bacteria associated with dairy productshavebeen Lactobacillus acidophilus, Lactobacillus casei, and bifidobacteria. Studies using animal models of diabetes have also shown that Lactobacillus acidophilus and Lactobacillus casei attenuate oxidativestress and have antidiabetic effects (Harisaet al., 2009; Yadav et $\boldsymbol{a l . , 2 0 0 7 ) . S o y m i l k ~ h a s ~ b e e n ~ a ~ r i c h ~ s o u r c e ~ o f ~ p r o t e i n ~ w h i c h ~ i s ~}$ inexpensive (Derbyshire et al., 1976)and abundantly available. Soymilk is used in various food products such as tofu, fruit flavored puddings, calcium and protein rich 
soymilk.In addition to protein, soybeans also contain various nutrients and functional components including isoflavonoids (Davis et al., 2005). Regular consumption of soy protein may help to reduce symptoms associated with type 2 diabetes. Soy has been shown to decrease postprandial hyperglycemia, to improve glucose toleranceand to decrease amounts of glycosylated hemoglobin (Heneman et al., 2007).

The fermentation of soymilk products changes the bioactive components, such as isoflavonoids and peptides, in ways which may alter their efficacy in the treatment of type 2 diabetes. Therefore, in this controlled trial, the current study aimed to investigate the effect of different milk types, conventional yoghurt and probiotic yoghurt from bifidobacterium on blood serum glucose and lipid profile for rats induced to diabetes.

\section{Subject and Methods}

\section{1 perpetration of Soymilk:}

Soybeans were obtained from local markets around Cairo city during winter 2018. The soybean seeds were washed and soaking soybeans in distilled water 10 times their weight at overnight, and the mixture was mixed in a blender. Then, the mixture filtered to make soymilk. The soymilk were sterilized at $121^{\circ} \mathrm{C}$ for $15 \mathrm{~min}$ and cooled to $37^{\circ} \mathrm{C}$ then stored at $4^{\circ} \mathrm{C}$ (Hou et al., 2000). 


\subsection{Cow Milk:}

Cow milk were obtained from local markets during winter 2018, and used as a raw materialto manufacture yoghurt and probiotic yoghurt.

\subsection{Whey protein:}

Ras cheese sweet whey was obtained from Dina Farms Company during winter 2018 for food as byproducts.

\subsection{Cultures:}

The bifidobacterial cultures were using DeManRogosa-Sharpe Broth Agar (MRS) medium.

\subsubsection{Yoghurt culture:}

Lyophilized culture for direct vat set "DVS" type Lactobacillus dulbrueekii sub sp. Bulgaricus and streptococcus salivarius subsp. Thermophiles were obtained from Dairy Microbiology Department, National Research center.

\subsubsection{Probiotic yoghurt culture:}

Highly concentrated and standardized freeze-dried culture for direct vat set "DVS" type Bifidobacterium infantisand bifidobacterium longum Bb-46 were obtained from Dairy Microbiology Department, National Research center.

\section{2-2 Methods:}

2.2.1Preparation of traditional yoghurt from milk and soymilk: 
Cow milk was inoculated with $3 \%$ of $1: 1$ mixture of S. salivariusssp thermophilius and L. dulbrueekii ssp bulgaricus wich were used as starter yoghurt culture according to (Tamime and robinson, 1988).

\subsubsection{Preparation of probiotic yoghurt from milk} and soymilk:

Cow milk was inoculated with $3 \%$ of $1: 1$ mixture ofbifidobacterium infantisand bifidobacterium longum $\mathrm{Bb}$ 46 wich were used as starter probiotic culture according to (El-sayed et al., 1998).

\section{Analytics methods part (1):}

\subsection{Chemical analysis:}

Protein $(\mathrm{N} \times 6.25)$, fat, ash, calcium $(\mathrm{Ca})$ determined according to the AOAC method (AOAC, 2007). Total carbohydrate was calculated by difference (Alvarez $\boldsymbol{e t}$ al., 2007). $\mathrm{PH}$ value was measured by using Orion $\mathrm{pH}-$ meter, model 501 at $20^{\circ} \mathrm{C}$.

\subsubsection{Animal feeding experiments:}

96 male albino rats average weight $(220 \pm 20 \mathrm{~g})$ were obtained from agriculture research center. They were housed in caged in temperature and humidity-controlled room. All rats fed for on basel diet for one week.

\subsubsection{Induction of diabetic:}

After acclimation, expect rats for group 1 (normal group), all remaining rats were injection with sterptozotocin (STZ) $0.55 \mathrm{mg} / \mathrm{kg}$ in sodium chloride $0.09 \%$ for 5 days. 
After injection animals were received $5 \%$ glucose solution overnight (wohaieb and godin,1987).

\subsubsection{Basal Diet}

Basal diet was composed of $37 \mathrm{~g}$ casein $(16 \%$ protein), $10 \mathrm{~g}$ corn oil ( $10 \%$ fat), $5 \mathrm{~g}$ cellulose $(5 \%$ fiber $), 4 \mathrm{~g}$ mineral mixture $(4 \%), 1 \mathrm{~g}$ vitamin mixture $(1 \%)$ and corn starch up to $100 \mathrm{~g}$ according to (Andersonet al.,1994).

\section{Design of the experiment:}

96 male albino rats of Sprague-Dawley strain. Every 8 rats placed in a cage and then we feed the rats on the basel diet.

\section{follows:}

The rats were divided into two main groups as The first main group (control negative group): consisting of eight rats were fed on the basel diet.

The second main group were divided into11 sub-groups contain 8 rats for each group injected first with sterptozotocin (STZ) $0.55 \mathrm{mg} / \mathrm{kg}$ in sodium chloride $0.09 \%$ for 5 daysto cause diabetes and divided into :

The first subgroup: fed on basel diet as a positive control group.

The second subgroup: fed on basel diet $+5 \mathrm{ml}$ milk.

The thired subgroup: fed on basel diet $+5 \mathrm{ml}$ soymilk.

The fourth subgroup: fed on basel diet $+5 \mathrm{ml}$ whey protein. 
The fifth subgroup: fed on basel diet +5 mlwhey protein and soymilk.

The sixth subgroup: fed on basel diet +50 gyoghurt from buffalo milk.

The seventh subgroup: fed on basel diet $+50 \mathrm{~g}$ yoghurt from soymilk.

The eights subgroup: fed on basel diet $+50 \mathrm{~g}$ yoghurt from soymilk and whey protein.

The nineth subgroup: fed on basel diet $+50 \mathrm{~g}$ probiotics from buffalo milkBb-12\& Bb-46.

The ten subgroup: fed on basel diet $+50 \mathrm{~g}$ probiotics from soymilk Bb-12\& Bb-46.

The eleven subgroup: fed on basel diet $+50 \mathrm{~g}$ probiotics from soy milk and whey protein Bb-12\& Bb-46.

\section{Biological Determination:}

The plasma glucose was determined at $546 \mathrm{~nm}$ according to the method described by (Tietz and Ash, 1995). Plasma total lipids were determined at wavelength $525 \mathrm{~nm}$ according to the method of(Knight et al., 1972).Total cholesterolwas determined at $546 \mathrm{~nm}$ according to the method of(Richmond,1973).Plasma high density lipoprotein-cholesterol (HDL-C) at 546 nmwas performed as described by (Fruchart, 1982). The serum uric acid was determined at $510 \mathrm{~nm}$ according to method reported by (Barham and Trinder, 1972). Serum urea nitrogen was determined at $550 \mathrm{~nm}$ according to the method described by (Fawcett and Soctt,1960). Serum creatinine was 
determined at $510 \mathrm{~nm}$ as given (Larsen, 1972). Alanine amino transferase (ALT) and aspartate amino transferase (AST) activities were determined calorimetrically at $505 \mathrm{~nm}$ according to the method of (Reitman and Frankel, 1957) for all parametersunder studying which had been estimated in serum samples were made by using spectrophotometer (model DU 4700) and were analyzed by using biodiagnostic and spectrum kits.

\section{Statistical analysis:}

The results were statistically analyzed using SSPS computer. Analysis of variance by one way ANOVA test using Ducan's multiple range tests.

\section{Result and discussion:}

\section{Serum blood glucose:}

Type 2 diabetes mellitus (T2DM) is the main form of diabetes and comprises more than $90 \%$ of people living with diabetes mellitus, worldwide (IDF, 2015). Diabetes and its complications are the leading causes of death globally and they are responsible for 5 to 20 percent of healthcare (Atkins, 2009).

The data present in Table (1) showed that the effect of different milk types, yoghurt from lactobacillus and yoghurt from bifidobacteriumon the plasma glucose level for diabetic rats. There were significant $(p \leq 0.05)$ increases in serum blood glucose in the positive control group compared with the negative and other groups because the injection with streptozotocin (STZ) can damage pancreatic $\beta$-cells. The mechanism of $\beta$-cells damage by STZ through 
transporting STZ into $\beta$-cells via glucose transporter GLUT2 (Szkudelski, 2012). The highest reduction in blood glucose was tended for probiotic yoghurt soy milk and conventional soy yoghurt.

Soy milk group has higher $(p<0.05)$ levels in decreasing plasma glucose than cow milk and whey protein in diabetic rats. These results are similar to those reported byMuelleret al., 2012 whom suggests that the context in which soy is consumed (unsweetened vs. sweetened) is likely important to reduce blood glucose in type 2 diabetics rats and reduce diabetes risk.

Moreover, it has also been posited that soy isoflavones inhibit insulin release from the pancreas and glucose uptake into the intestinal brush border by restraining protein tyrosine kinase activity (Akiyama et al., 1996) or decreasing sodium-dependent glucose transporters (Vedavanam et al., 1999). An alternative hypothesis is that soy isoflavones are a marker of a healthy soy-based diet. Regular consumption of soy protein may help to reduce symptoms associated with type 2 diabetes. Soy has been shown to decrease hyperglycemia, to improve glucose tolerance, and to decrease amounts of glycosylated hemoglobin (Heneman et al., 2007).

The results reported that the groups feed on fermentation yoghurt from bifidobacterium and Lactobacillus of soy milk and cow milk groups showed significant $(\mathrm{p} \leq 0.05)$ decreased plasma glucose than the groups which fed on soy milk and cow milk without fermentation. The decreasing may be due to fermentation 
Nada Mohamed Afifi

improved nutritional and functional properties and increased content of small bioactive compounds (Chien et al., 2006).Fermentation can also enhance nutritional and functional possessions of food by transformation of substrates into bioactive molecules (Marco et al., 2017). In this context, fermentation of soybean/soy milk has reported to improve bioavailability of isoflavones, assists in digestion of protein, and provide more soluble calcium, reduced level of carbohydrates and increased level of bioactive isoflavones and bioactive peptides in ways which may alter their efficacy in the treatment of type 2 diabetes (Young et al., 2010 \& Singh et al., 2014).

Table (1) The Effect of Different milk (cow, soya and Sweet whey protein) and its yoghurt by various types of bacterial culture on blood glucose for rats induced to diabetes.

\begin{tabular}{|c|c|c|c|c|c|c|}
\hline & Groups & $\begin{array}{l}\text { Initial } \\
\text { Glucose }\end{array}$ & $\begin{array}{c}\text { After } \\
2 \text { weeks }\end{array}$ & $\begin{array}{c}\text { After } \\
\text { 4 weeks }\end{array}$ & $\begin{array}{c}\text { After } \\
\text { 6 weeks }\end{array}$ & $\begin{array}{c}\text { Percentage } \\
\text { of glucose } \\
\text { reduction }\end{array}$ \\
\hline \multicolumn{2}{|c|}{ Control negative group $(-)$} & $90.8^{\mathrm{b}} \pm 4.6$ & $89.8^{\mathrm{e}} \pm 7.12$ & $90.2^{e^{\circ}} \pm 3.7$ & $88.6^{\circ} \pm 2.7$ & $2 \%$ \\
\hline \multicolumn{2}{|c|}{ Control positive group $(+)$} & $321.4^{\mathrm{a}} \pm 10.9$ & $329.4^{\mathrm{a}} \pm 12.7$ & $319.2^{\mathrm{a}} \pm 17.1$ & $312.6^{\mathrm{a}} \pm 19.6$ & $2.7 \%$ \\
\hline \multirow{4}{*}{ 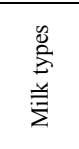 } & cow milk & $324.2^{\mathrm{ab}} \pm 10.9$ & $238.4^{\mathrm{b}} \pm 18.8$ & $212.4^{\mathrm{b}} \pm 11.2$ & $144.4^{\mathrm{bC}} \pm 14.4$ & $55 \%$ \\
\hline & Soymilk & $297.4^{\text {ab }} \pm 23$ & $192.2^{\text {cd }} \pm 14.5$ & $145^{\text {cd }} \pm 14.2$ & $101.4^{\mathrm{d}} \pm 5.8$ & $66 \%$ \\
\hline & Whey protein & $303.4^{\mathrm{ab}} \pm 15.2$ & $247^{b} \pm 12.2$ & $214.4^{\mathrm{b}} \pm 12.1$ & $153.4^{\mathrm{b}} \pm 10.7$ & $49 \%$ \\
\hline & $\begin{array}{l}\text { Whey protein } \\
\text { and soymilk }\end{array}$ & $295.6^{\mathrm{ab}} \pm 28$ & $193^{\text {cd }} \pm 20.1$ & $155.4^{\mathrm{c}} \pm 15$ & $110.4^{\mathrm{d}} \pm 10.3$ & $62 \%$ \\
\hline \multirow{3}{*}{ 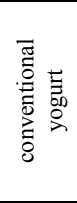 } & $\begin{array}{c}\text { Yoghurt from } \\
\text { cow milk }\end{array}$ & $300^{\text {ab }} \pm 19.9$ & $229.4^{b} \pm 14.3$ & $197.4^{\mathrm{b}} \pm 17.2$ & $135^{\mathrm{c}} \pm 9.4$ & $55 \%$ \\
\hline & $\begin{array}{c}\text { Yoghurt from } \\
\text { soymilk }\end{array}$ & $312^{\mathrm{ab}} \pm 24.1$ & $187^{\mathrm{d}} \pm 14.2$ & $132.6^{\mathrm{d}} \pm 12.3$ & $99.6^{\mathrm{d}} \pm 7.5$ & $68 \%$ \\
\hline & $\begin{array}{l}\text { Yoghurt from } \\
\text { soymilk and } \\
\text { whey protein }\end{array}$ & $315.4^{\mathrm{ab}} \pm 30.7$ & $190.8^{\mathrm{e}} \pm 18.4$ & $141.6^{\mathrm{cd}} \pm 17.3$ & $101.6^{\mathrm{d}} \pm 10.4$ & $68 \%$ \\
\hline \multirow{3}{*}{ 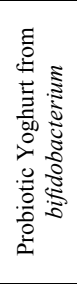 } & $\begin{array}{l}\text { probiotic } \\
\text { yoghurt from } \\
\text { cow milk }\end{array}$ & $312^{\mathrm{ab}} \pm 17.4$ & $213.6^{\mathrm{bc}} \pm 13.2$ & $194.6^{\mathrm{b}} \pm 19.9$ & $124.4^{\mathrm{c}} \pm 16.3$ & $57 \%$ \\
\hline & $\begin{array}{c}\text { probiotic } \\
\text { yoghurt from } \\
\text { soymilk }\end{array}$ & $318^{\mathrm{ab}} \pm 27.7$ & $181.2^{d} \pm 26.8$ & $126.8^{d} \pm 12.9$ & $94.8^{\mathrm{d}} \pm 6.4$ & $70 \%$ \\
\hline & $\begin{array}{c}\text { probiotic } \\
\text { yoghurt from } \\
\text { soymilk and } \\
\text { whey protein }\end{array}$ & $316.4^{\mathrm{ab}} \pm 31.3$ & $187.4^{\mathrm{d}} \pm 22.4$ & $140.8^{\text {cd }} \pm 17.8$ & $100.4^{\mathrm{d}} \pm 6.3$ & $68 \%$ \\
\hline
\end{tabular}

that there were statically significant differents at $(\mathrm{P}<0.05)$. 
The results showed that the group fed on the probiotic yoghurt from bifidobacterium soymilk and cow milk is significantly $(\mathrm{p} \leq 0.05)$ decreased the level of plasma glucose compare with Lactobacillus yoghurt of soymilk and cow milk group. This result is in agreement with Ejtahedet al., 2012, who reported that probiotic yogurt significantly decreased fasting blood glucose $(\mathrm{P}<0.05)$.

\section{Serum lipid profile:}

Cardiovascular disease, as one of several chronic disorders, is the major complication of type 2 diabetes mellitus (T2DM). Cardio-vascular disease may result from associated abnormalities of plasma lipid and lipoprotein metabolism (Dunn, 2010). Alteration in plasma lipid and lipoprotein profile has been documented in diabetic (Shafrir \& Raz, 2003).People affected with hypercholesterolemia may avert the use of cholesterollowering drugs by practicing dietary control or supplementation of probiotics and/or prebiotics (Roberfroid, 2005).

The data illustrated in Table (2), showed the effects of different milk types, yoghurt from lactobacillus and probiotic yoghurt from bifidobacterium on serum total cholesterol and triglycerides in normal and diabetics rats. The results revealed that, the serum total cholesterol and triglycerides in control positive group were significant at $(p \leq 0.05)$ decrease between among all studies groups. The best result showed in the group fed on probiotic soy yoghurt when compare with control negative group. The probiotic 
soy yoghurt from bifidobacterium group has decrees value of TC and TG than other groups.

The soy milkgroup showed significant at $(\mathrm{p} \leq 0.05)$ differences among cow and whey protein because soymilk contain isoflavones that lead to decreasing the TC and TG. The result was agreed with the many previous studies (Sirtori etal., 2002 , Teixeira etal., 2000 \& Wang etal ., 2004). Desroches etal., 2004 whom suggest that the consumption of a soy protein diet may induce cardio protective and beneficial changes in the LDL size phenotype and that those effects are independent of the isoflavone component of soy.

Table (2): The Effect of Different milk (cow, soya and Sweet whey protein) and its yoghurt by various types of bacterial culture on lipid profile for rats induced to diabetes.

\begin{tabular}{|c|c|c|c|c|c|}
\hline \multirow{2}{*}{\multicolumn{2}{|c|}{ Groups }} & \multicolumn{4}{|c|}{ mg/dl Mean SD \pm} \\
\hline & & $\begin{array}{c}\text { Total } \\
\text { cholesterol }\end{array}$ & $\begin{array}{l}\text { Percentag } \\
\text { e of total } \\
\text { cholesterol } \\
\text { reduction }\end{array}$ & Triglycerides & $\begin{array}{l}\text { Percentage } \\
\text { of } \\
\text { triglycerides } \\
\text { reduction }\end{array}$ \\
\hline \multicolumn{2}{|c|}{ Control negative group $(-)$} & $83.8^{\mathrm{e}} \pm 4.1$ & - & $78.1^{\mathrm{d}} \pm 2.1$ & - \\
\hline \multicolumn{2}{|c|}{ Control positive group $(+)$} & $123.5^{\mathrm{a}} \pm 3.6$ & - & $103.7^{\mathrm{a}} \pm 3.3$ & - \\
\hline \multirow{4}{*}{ 芯 } & cow milk & $96.1^{\mathrm{b}} \pm 4.7$ & $22.1 \%$ & $89.5^{\mathrm{bc}} \pm 2.9$ & $13.6 \%$ \\
\hline & Soymilk & $94.9^{b} \pm 2.06$ & $23.1 \%$ & $83.2^{\mathrm{c}} \pm 1.7$ & $19.7 \%$ \\
\hline & Whey protein & $119.5^{\mathrm{a}} \pm 3$ & $3.2 \% \%$ & $99.1^{b} \pm 3.6$ & $4.4 \%$ \\
\hline & $\begin{array}{l}\text { Whey protein } \\
\text { and soymilk }\end{array}$ & $98.8^{\mathrm{b}} \pm 3.1$ & $20.0 \%$ & $90.3^{\mathrm{b}} \pm 3.1$ & $12.9 \%$ \\
\hline \multirow{3}{*}{ 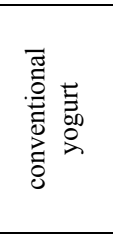 } & $\begin{array}{l}\text { Yoghurt from } \\
\text { cow milk }\end{array}$ & $92.6^{\mathrm{cb}} \pm 2.8$ & $25.0 \%$ & $84.2^{\mathrm{c}} \pm 1.4$ & $18.8 \%$ \\
\hline & $\begin{array}{l}\text { Yoghurt from } \\
\text { soymilk }\end{array}$ & $88.3^{\mathrm{d}} \pm 3.7$ & $28.5 \%$ & $80.4^{\mathrm{c}} \pm 1.6$ & $22.4 \%$ \\
\hline & $\begin{array}{l}\text { Yoghurt from } \\
\text { soymilk and } \\
\text { whey protein }\end{array}$ & $91.8^{\mathrm{c}} \pm 2.4$ & $25.6 \%$ & $83.1^{\mathrm{c}} \pm 1.6$ & $19.8 \%$ \\
\hline \multirow{3}{*}{ 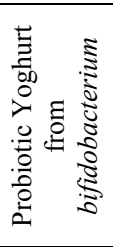 } & $\begin{array}{l}\text { probiotic } \\
\text { yoghurt from } \\
\text { cow milk }\end{array}$ & $90.4^{\mathrm{c}} \pm 2.3$ & $26.8 \%$ & $81.3^{\mathrm{c}} \pm 2.6$ & $12.6 \%$ \\
\hline & $\begin{array}{c}\text { probiotic } \\
\text { yoghurt from } \\
\text { soymilk } \\
\end{array}$ & $84.3^{\mathrm{e}} \pm 2.1$ & $31.7 \%$ & $77.4^{\mathrm{d}} \pm 2.7$ & $25.3 \%$ \\
\hline & probiotic & $88.5^{\mathrm{c}} \pm 3.3$ & $28.3 \%$ & $80.9^{c} \pm 2.07$ & $21.9 \%$ \\
\hline
\end{tabular}


The Effect of Different milk types and its yoghurt by various types of Bacterial Culture on Rats induced to Diabetes

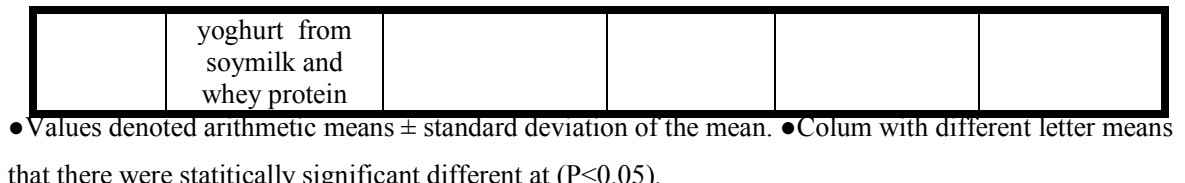

The groups fed on the fermentation yoghurt from bifidobacterium and Lactobacillus of soymilk and cow milk groups showed significant at $(\mathrm{p} \leq 0.05)$ differences than among the rats fed soy milk and cow milk without fermentation. The fermentation has beneficial health effects on their host, when enter the intestine with an adequate amount. Some of these health effects include: lowering hypercholesterolemia, lactose intolerance, diabetes mellitus (Zhuang etal., 2012).

The result showed that the group fed on the probiotic yoghurt from bifidobacterium soymilk and cow milk is significantly $(\mathrm{p} \leq 0.05)$ decrease. The level of TC and TG compare with Lactobacillus yoghurt of soymilk and cow milk group. This result is in agreement with Mohamadshahi et al., 2014 who suggest that consuming probiotic yogurt can improve lipid abnormalities in patients with T2DM.

Some studies indicated that probiotics may be able to prevent increased levels of total cholesterol (TC), LDL-c and balance the ratio of LDL-c/HDL-c by deconjugating of bile, hydrolysis of bile salts and increase cholesterol absorption, which consequently prevent and reduce the prevalence of cardio-vascular diseaseand reduce diabetics complications (Baroutkoubet al., 2010). The results are in agreement with Lee $\boldsymbol{e t}$ al., 2009 whom showed that short 
chain fatty acids that are produced by lactic acid bacteria could inhibit the enzymatic synthesis of cholesterol. Probiotic bacteria may also facilitate excreting of cholesterol through feces (Begley et al., 2006). Furthermore, these bacteria can assimilate cholesterol and lead to its reduction. Moreover, it is suggested that bifidobacteria bacteria may bind with cholesterol and inhibit its reabsorption in the body (Ooi \& Liong, 2010).

\section{Serum lipoprotein HDL, LDL and VLDL-c:}

Data present in Table ( 3 ), showed the effect of different milk types, yoghurt from lactobacillus and probiotics yoghurt from bifidobacterium on blood serum lipid profile for diabetic rats. The results revealed that, the serum of HDL-C, LDL-C and VLDL-C showed significant $(\mathrm{p} \leq 0.05)$ differences among all studies groups at $(\mathrm{p} \leq 0.05)$ compare with control positive group. The group feed on soymilk showed significant $(p \leq 0.05)$ differences among cow and Whey protein that means the soy milk was more effective than cow milk in increasing serum HDL value and decreasing serum VLDL-C and LDL-C value in diabetic rats.This is due to soymilk contained isoflavones, Postulated mechanisms include inhibition of cholesterol absorption or enhanced bile acid excretion, and increased receptor mediated clearance (Khosla $\boldsymbol{e t}$ al., 1991) LDL receptor activity hydroxylase activity (Potter, 1990).

The group feed on the probiotic yoghurt bifidobacterium is more effective than group feed on Lactobacillus yoghurt of soymilk and cow milk group. Therefore, return to the probiotic active in assimilate cholesterol and lead to its reduction. Previous studies on 
The Effect of Different milk types and its yoghurt by various types of Bacterial Culture on Rats induced to Diabetes

probiotic have reported beneficial effects on serum lipid profiles there is more effect than those made by conventional yogurt (Kaushik et al., 2009 \& Agerbaek et al.,1995). The result showed that the probiotic soy yoghurt from bifidobacterium group had the highest value HDl than other groups. On the other hand the probiotic yoghurt soymilk group had lowest value of VLDL-C and (LDL-C) cholesterol in rats.

Table (3) The Effect of Different milk (cow, soya and Sweet whey protein) and its yoghurt by various types of bacterial culture on serum lipoprotein fraction for rats induced to diabetes.

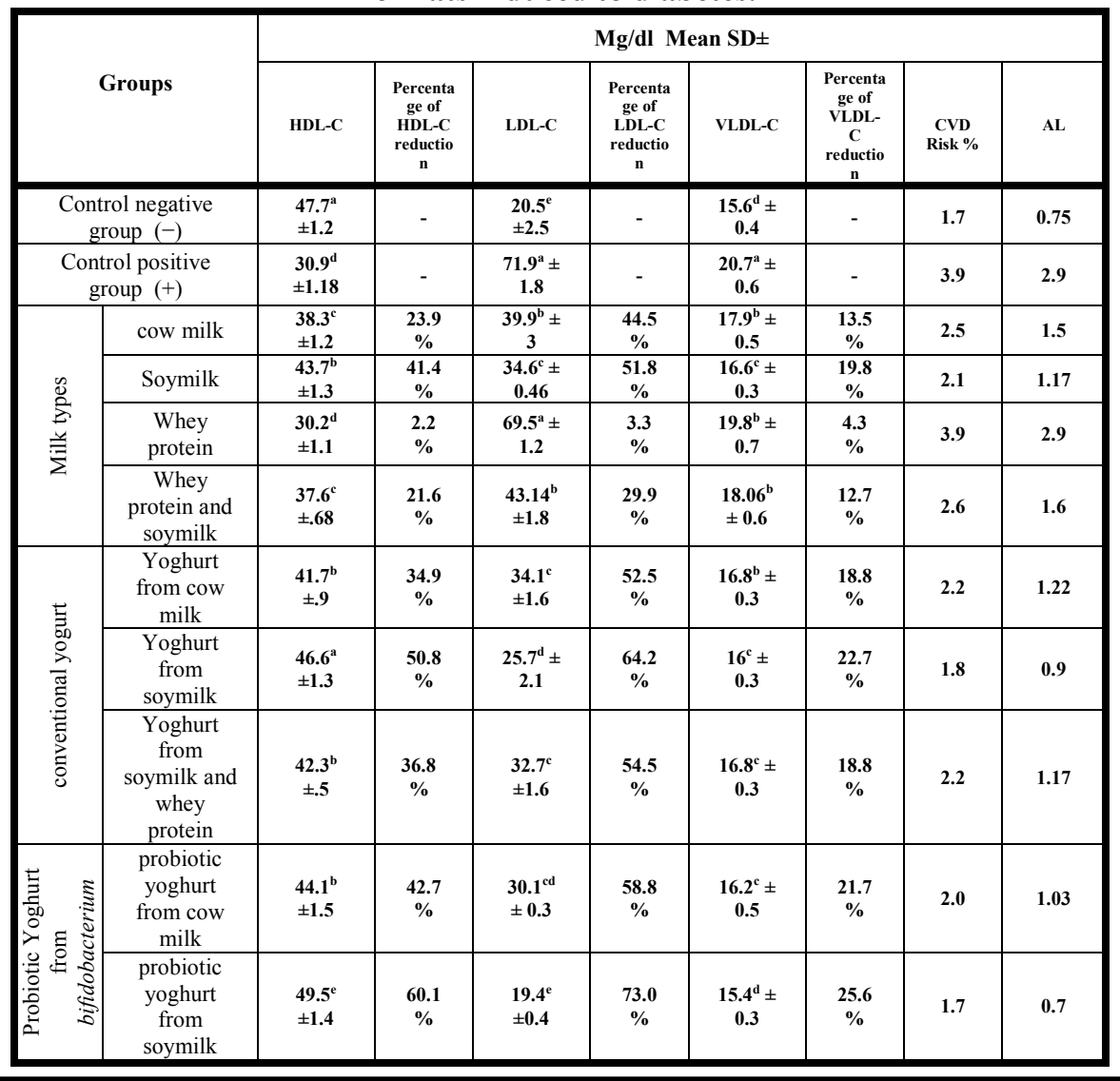

Egyptian Journal for Specialized Studies - Vol (8) N (26) April 2020 
Nada Mohamed Afifi

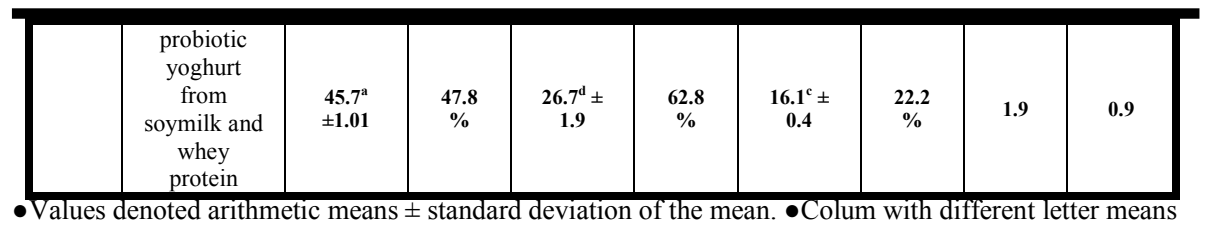

that there were statically significant different at $(\mathrm{P}<0.05)$.

The rats fed on the yoghurt from bifidobacterium and Lactobacillus of soymilk groups showed significant at $(\mathrm{p} \leq 0.05)$ differences among the rats fed soymilk without fermentation this is due to the fermentation improved the lipid profiles and enhances the viability of these microorganisms. This result was in general agreed with the many previous studies(Beavers et al., 2010, Vij et al., 2011 and Wang et al ., 2004 ). Champagne et al., 2009 reported soymilk fermented with Bifidobacterium significantly decreased the levels of very low-density lipoprotein (VLDL) and low-density lipoprotein (LDL)-cholesterol in rats. These results are approximately in agreement with Wang et al ., (2004) who reported that fermented soy yoghurt with bifidobacterium significantly decreased the levels of total plasma cholesterol, VLDL and LDLcholesterol in rats.

The probiotic soy yoghurt from bifidobacterium and Lactobacillus of groups has higher HDl-c value and lower VLDL and LDL cholesterol than the yoghurt from bifidobacterium and Lactobacillus of cow milk. Soy isoflavones in soy yoghurt improves serum lipid profiles, vascular reactivity, and protection of LDL against oxidation. 


\section{Conclusion:}

This trial showed that consuming soy-protein consumption reduces serum blood glucose and lipid profile. Probiotic yogurt from soy milk

improved the lipid profile status and on rats induced to diabetes. These findings suggest that probiotic yogurt is a functional food that can exert antidiabetic.

\section{Reference:}

1. Abdel-Gawad, I. A., Hefny, A. A., El-Sayed, E. M., \& Saleh, F. A. (1998). Reduction of flatulence-causing soymilk oligosaccharides by different starter cultures. In 7. Egyptian Conference for Dairy Science and Technology, Cairo (Egypt), 7-9 Nov 1988.

2. Agerbaek M, Gerdes LU, Richelsen B.(1995). Hypocholesterolaemic effect of a new fermented milk product in healthy middle-aged men. Eur J Clin Nutr., 1995;49:346352.

3. Alvarez-Parrilla, E., De la Rosa, L. A., Martínez, N. R., \& González, G. A. (2007). TOTAL PHENOLS AND ANTIOXIDANT ACTIVITY OF COMMERCIAL AND WILD MUSHROOMS FROM CHIHUAHUA, MEXICO FENOLES TOTALESY CAPACIDAD ANTIOXIDANTE DE HONGOS COMERCIALESY SILVESTRES DE CHIHUAHUA, MÉXICO. CYTA-Journal of Food, 5(5), 329334.

4. Akiyama, Y., Lueßen, H. L., de Boer, A. B. G., Verhoef, J. C., \& Junginger, H. E. (1996). Novel peroral dosage forms with protease inhibitory activities. II. Design of fast dissolving poly (acrylate) and controlled drug-releasing capsule formulations with trypsin inhibiting properties. International journal of pharmaceutics, 138(1), 13-23. 
5. Anderson, J. W., Jones, A. E., \& Riddell-Mason, S. (1994). Ten different dietary fibers have significantly different effects on serum and liver lipids of cholesterol-fed rats. The Journal of nutrition, 124(1), 78-83.

6. AOAC (2007). Official Methods of Analysis of AOAC International, 18th ed. Association of Official Analytical Chemists, Washington,DC. USA.

7. Atkins RC, Zimmet P. (2009). Diabetic kidney disease: Act now or pay later. Pediatric Nephrology. 11(2):181.

8. Atlas, D.International Diabetes Federation. IDF Diabetes Atlas, 7th edn. Brussels, Belgium: International Diabetes Federation, 2015.

9. Barham, D., \& Trinder, P. (1972). An improved colour reagent for the determination of blood glucose by the oxidase system. Analyst, 97(1151), 142-145.

10. Baroutkoub, A., Mehdi, R. Z., Beglarian, R., Hassan, J., Zahra, S., \& Mohammad, M. S. (2010). Effects of probiotic yoghurt consumption on the serum cholesterol levels in hypercholestromic cases in Shiraz, Southern Iran. Scientific Research and Essays, 5(16), 2206-2209.

11. Beavers K. M., Serra M. C., Beavers D. P., Hudson G. M., \& Willoughby D. S. (2010). The lipid-lowering effects of 4 weeks of daily soymilk or dairy milk ingestion in a postmenopausal female population. Journal of medicinal food, 13(3), 650-656.

12. Begley, M., Hill, C., \& Gahan, C. G. (2006). Bile salt hydrolase activity in probiotics. Appl. Environ. Microbiol., 72(3), 1729-1738.

13. Chien H.L., Huang H.Y. and Chou C.C. (2006). Transformation of isoflavone phytoestrogens during the fermentation of soymilk with lactic acid bacteria and bifidobacteria. Food microbiology, 23(8): 772-778.

14. Chuayana Jr, E. L., Ponce, C. V., Rivera, M. R. B., \& Cabrera, E. C. (2003). Antimicrobial activity of probiotics from milk products. Phil J. Microbiol. Infect. Dis, 32(2), 7174. 
15. Davis, J., Iqbal, M. J., Steinle, J., Oitker, J., Higginbotham, D. A., Peterson, R. G., \& Banz, W. J. (2005). Soy protein influences the development of the metabolic syndrome in male obese ZDFxSHHF rats. Hormone and metabolic research, 37 (05), 316-325.

16. Derbyshire, E., Wright, D. J., \& Boulter, D. (1976). Legumin and vicilin, storage proteins of legume seeds. Phytochemistry, 15(1), 3-24.

17. Desroches, S., Mauger, J. F., Ausman, L. M., Lichtenstein, A. H., \& Lamarche, B. (2004). Soy protein favorably affects LDL size independently of isoflavones in hypercholesterolemic men and women. The Journal of nutrition, 134(3), 574579.

18. Dunn FL. (2010). Management of dyslipidemia in people with type 2 diabetes mellitus. Rev Endocr Metab Disord. 11:41-51.

19. Dunn, F. L. (2010). Management of dyslipidemia in people with type 2 diabetes mellitus. Reviews in endocrine and metabolic disorders, 11(1), 41-51.

20. Ejtahed, H. S., Mohtadi-Nia, J., Homayouni-Rad, A., Niafar, M., Asghari-Jafarabadi, M., \& Mofid, V. (2012). Probiotic yogurt improves antioxidant status in type 2 diabetic patients. Nutrition, 28(5), 539-543.

21. Fawcett, J. K., \& Scott, J. (1960). A rapid and precise method for the determination of urea. Journal of clinical pathology, 13(2), 156-159.

22. Fruchart, G. G. (1982). LDL-Cholesterol determination after separation of low density lipoprotein. Rev. Fr. Des. Laboratories, 103(7), 117.

23. Harisa, G. I., Taha, E. I., Khalil, A. F., \& Salem, M. M. (2009). Oral administration of Lactobacillus acidophilus restores nitric oxide level in diabetic rats. Aust J Basic Appl Sci, 3(3), 2963-2969.

24. Heneman K. M., Chang, H. C., Prior R. L., \& Steinberg F. M. (2007). Soy protein with and without isoflavones fails to 
substantially increase postprandial antioxidant capacity. The Journal of nutritional biochemistry, 18(1), 46-53.

25. Heneman, K., Steinberg, F., and Zidenberg-Cherr, S. (2007). Some fact about soy. Nutrition and Health Info-Sheet. UC Cooperative Extension Center for Health and Nutrition Research, Department of Nutrition, University of California. 14.

26. Hou J., Yu R. \& Chou, C. (2000). Changes in some components of soymilk during fermentation with bifidobacteria. Food Research International, 33(5), 393-397. in the liver of young rats. J. Nutr. 139:905-911.

27. Kaushik JK, Kumar A, Duary RK, Mohanty AK, Grover S, Batish VK. (2009). Functional and probiotic attributes of an indigenous isolate of Lactobacillus plantarum. PLoS ONE 2009; 4:e8099.

28. Kaushik, J. K., Kumar, A., Duary, R. K., Mohanty, A. K., Grover, S., \& Batish, V. K. (2009). Functional and probiotic attributes of an indigenous isolate of Lactobacillus plantarum. PloS one, 4(12), e8099.

29. Khosla, P. K., Papanikolopoulos, N. \& Kanada, T. (1991, April). Vision and control techniques for robotic visual tracking. In Proceedings. 1991 IEEE International Conference on Robotics and Automation (pp. 857-864). IEEE.

30. Knight, J. A., Anderson, S., \& Rawle, J. M. (1972). Chemical basis of the sulfo- phospho-vanillin reaction for estimating total serum lipids. Clinical chemistry, 18(3), 199202.

31. Larsen, K. (1972). Creatinine assay by a reaction-kinetic principle. Clinica chimica acta, 41, 209-217.

32. Lee, S.Y., Morr, C. V., \& Seo, A. (1990). Comparison of milk-based and soymilk-based yogurt. Journal of Food Science, 55(2), 532-536.

33. Marco M. L., Heeney D., Binda, S., Cifelli C. J., Cotter P. D., Foligné, B. \& Smid, E. J. (2017). Health benefits of fermented foods: microbiota and beyond. Current opinion in biotechnology, 44, 94-102. 
34. Mohamadshahi, M., Veissi, M., Haidari, F., Javid, A. Z., Mohammadi, F., \& Shirbeigi, E. (2014). Effects of probiotic yogurt consumption on lipid profile in type 2 diabetic patients: A randomized controlled clinical trial. Journal of research in medical sciences: the official journal of Isfahan University of Medical Sciences, 19(6), 531.

35. Mueller N. T., Odegaard A. O., Gross M. D., Koh W. P., Mimi, C. Y., Yuan, J. M., \& Pereira, M. A. (2012). Soy intake and risk of type 2 diabetes mellitus in Chinese Singaporeans. European journal of nutrition, 51(8), 10331040.

36. Ooi LG, Liong MT. (2010). Cholesterol-lowering eff ects of probiotics and prebiotics: A review of in vivo and in vitro fi ndings. Int J Mol Sc., 2010;11:2499-522.

37. Potter, S. M. (1995). Overview of proposed mechanisms for the hypocholesterolemic effect of soy. The Journal of nutrition, 125(suppl_3), 606S-611S.

38. Rader, D. J. (2007). Effect of insulin resistance, dyslipidemia, and intra-abdominal adiposity on the development of cardiovascular disease and diabetes mellitus. The American journal of medicine, 120(3), S12-S18.

39. Reitman, S., \& Frankel, S. (1957). A colorimetric method for the determination of serum glutamic oxalacetic and glutamic pyruvic transaminases. American journal of clinical pathology, 28(1), 56-63.

40. Roberfroid, M. (2007). Prebiotics: the concept revisited. The Journal of nutrition, 137(3), 830S-837S.

41. Shafrir E, Raz I. (2003). Diabetes: Mellitus or lipidus? Diabetologia 2003;46:433-40.

42. Shafrir, E., \& Raz, I. (2003). Diabetes: mellitus or lipidus . Diabetologia, 46(3),433-440.

43. Singh B.P., Vij S. and Hati S. 2014. Functional significance of bioactive peptides derived from soybean. Peptides 54: 171179. 
Nada Mohamed Afifi

44. Sirtori CR, Bosisio R, Pazzucconi F, Bondioli A, Gatti E, Lovati MR, et al. (2002). Soy milk with a high glycitein content does not reduce low-density lipoprotein cholesterolemia in type II hypercholesterolemic patients. Ann Nutr Metab, 46:88-92.

45. Song, W. O., Chun, O. K., Hwang, I., Shin, H. S., Kim, B. G., Kim, K. S., ... \& Lee, S. G. (2007). Soy isoflavones as safe functional ingredients. Journal of medicinal food, 10(4), 571-580.

46. Szkudelski T. (2012). Streptozotocin-nicotinamide-induced diabetes in the rat. Characteristics of the experimental model. Experimental biology and medicine, 237(5), 481-490.

47. Tamime, A. Y., \& Robinson, R. K. (1988). Fermented milks and their future trends. Part II. Technological aspects. Journal of Dairy Research, 55(2), 281-307.

48. Teixeira SR, Potter SM, Weigel R, Hannum S, Erdman Jr JW, Hasler CM. (2000). Effects of feeding levels of soy protein for 3 and 6 wk on blood lipids and apolipoproteins in moderately hypercholesterolemic men. Am J Clin Nutr., 71:1077-84.

49. Tietz, N. W., \& Ash, K. O. (1995). Clinical Guide to Laboratory Tests. Clinical Chemistry, 41(10), 1548-1548.

50. Vedavanam, K., Srijayanta, S., O'Reilly, J., Raman, A., \& Wiseman, H. (1999). Antioxidant action and potential antidiabetic properties of an isoflavonoid-containing soyabean phytochemical extract (SPE). Phytotherapy Research: An International Journal Devoted to Pharmacological and Toxicological Evaluation of Natural Product Derivatives, 13(7), 601-608.

51. Vij S., Hati S., \& Yadav D. (2011). Biofunctionality of probiotic soy yoghurt. Food and Nutrition Sciences, 2(05), 502.

52. Wang P. and Jones L. M. (2004). Ausman and A. H. Lichtenstein, "Soy Protein Reduces Triglyceride Levels and Triglyceride Fatty Acid Fractional Synthesis Rate in Hy- 
percholes-terolemic Subjects," Atherosclerosis, Vol. 173, No. 2, 2004, pp. 269-275.

53. Wang, Q., Ge, X., Tian, X., Zhang, Y., Zhang, J., \& Zhang, P. (2013). Soy isoflavone: The multipurpose phytochemical. Biomedical reports, 1(5), 697-701.

54. Wohaieb, S. A., \& Godin, D. V. (1987). Alterations in free radical tissue-defense mechanisms in streptozocin-induced diabetes in rat: effects of insulin treatment. Diabetes, 36(9), 1014-1018.

55. Yadav, H., Jain, S., \& Sinha, P. R. (2007). Antidiabetic effect of probiotic dahi containing Lactobacillus acidophilus and Lactobacillus casei in high fructose fed rats. Nutrition, 23(1), 62-68.

56. Young, K. S., \& De Abreu, C. N. (Eds.). (2010). Internet addiction: A handbook and guide to evaluation and treatment. John Wiley \& Sons.

57. Zhuang, G., Liu, X. M., Zhang, Q. X., Tian, F. W., Zhang, H., Zhang, H. P., \& Chen, W. (2012). Research advances with regards to clinical outcome and potential mechanisms of the cholesterol-lowering effects of probiotics. Clinical Lipidology, 7(5), 501-507. 